Jurnal Civics: Media Kajian Kewarganegaraan
https://journal.uny.ac.id/index.php/civics/index
$1829-5789$ (print)
$2541-1918$ (online)

\title{
Dampak sosialisasi empat pilar MPR RI terhadap Pendidikan Pancasila di perguruan tinggi
}

\author{
Hastangka $^{a, 1^{*}}$, Armaidy Armawi ${ }^{\text {b, } 2}$, Kaelan ${ }^{c, 3}$ \\ a,b,c Fakultas Filsafat Universitas Gadjah Mada, Yogyakarta Indonesia \\ ${ }^{1}$ hastangka@gmail.com*; ${ }^{2}$ armaidy@ugm.ac.id; ${ }^{3}$ kaelanms@ yahoo.com \\ *korespondensi penulis
}

\begin{tabular}{ll}
\hline \multicolumn{2}{l}{ Informasi Artikel } \\
\hline Sejarah artikel & \\
Diterima & $: 07-11-2018$ \\
Revisi & $: 17-12-2018$ \\
Dipublikasikan & $: 31-10-2019$ \\
\hline
\end{tabular}

Kata kunci:

Sosialisasi

Pendidikan Pancasila

Empat Pilar

MPR RI

Perguruan Tinggi

\begin{abstract}
ABSTRAK
Penggunaan istilah empat pilar kehidupan berbangsa dan bernegara untuk program sosialisasi telah menimbulkan polemik dan perdebatan di masyarakat. Empat pilar tersebut meliputi Pancasila, UUD 1945, NKRI, dan Bhinneka Tunggal Ika yang dirumuskan oleh MPR RI. Tujuan penelitian ini adalah untuk mendeskripsikan dampak sosialisasi Empat Pilar tersebut terhadap pendidikan Pancasila di perguruan tinggi. Data penelitian diambil dari buku, jurnal ilmiah, artikel surat kabar, dan berita di media online ataupun offline, dan dokumen yuridis, seperti peraturan perundang-undangan. Analisis data menggunakan pendekatan interpretatif, induksi-analitis, semiotik, dan analisis wacana. Hasil penelitian ini menunjukkan bahwa (1) sosialisasi empat pilar berdampak pada ambiguitas pemaknaan dan pemahaman baik dari peserta didik maupun dosen dalam pembelajaran Pancasila sebagai dasar atau pilar kehidupan bernegara dan berbangsa, dan (2) penggunaan istilah empat pilar telah mengacaukan pemahaman dan pengetahuan para peserta didik dalam memahami Pancasila.
\end{abstract}

\author{
Keywords: \\ Public education \\ Pancasila education \\ Four Pillars \\ MPR RI \\ Higher Education
}

\begin{abstract}
The application of the term "Four Pillars of Life of the People and the Nation" in socialization creates polemic and debate in society. Those four pillars are Pancasila, the 1945 Constitution, the Unitary State of the Republic of Indonesia, and Unity in Diversity, which formulated by the People's Consultative Assembly of the Republic of Indonesia. The objective of this research is to investigate the impact that socialization has on the education of Pancasila in a higher level of education. The research data obtained from books, scientific journals, newspaper articles, other online and offline sources, and legal documents, for instance, legislation. Interpretative, analytic-induction, semiotic, and disclosure approaches applied to the analysis. The result shows that the socialization has immense impacts on 1). The ambiguity toward the meaning and the understanding by both students and lecturers in learning Pancasila as the pillar of the life of the people and the nation, and 2). The use of the term "four pillars" has disrupted the understanding and the knowledge of students in their comprehension toward Pancasila.
\end{abstract}

Copyright (ㄷ 2019 Hastangka Armaidy Armawi, dan Kaelan

\section{Pendahuluan}

Penggunaan istilah empat pilar kehidupan berbangsa dan bernegara yang dirumuskan oleh Majelis Permusyawaratan Rakyat Republik Indonesia (MPR RI) untuk program sosialisasi telah menimbulkan polemik dan perdebatan di masyarakat. Pokok awal persoalan yang diperdebatkan ialah penggunaan istilah empat pilar kehidupan berbangsa dan bernegara yang mengategorikan Pancasila, UUD 1945, NKRI, dan Bhinneka Tunggal Ika dalam satu 
varian yang sama disebut pilar. Polemik dan perdebatan ini mengemuka dalam berbagai situasi mulai dari pandangan akademisi yang mencoba untuk mengkritisi dan mengoreksi penggunaan istilah Empat Pilar yang dianggap mendegradasikan makna dan pemahaman Pancasila sebagai dasar negara sampai pada pandangan masyarakat yang mempersoalkan pilarisasi yang dilakukan oleh MPR RI terhadap dasar negara yaitu Pancasila.

Pancasila dalam memori dan imajinasi masyarakat Indonesia merupakan dasar negara. Pancasila sebagai dasar negara memiliki kedudukan dan fungsi fundamental dalam kehidupan bernegara yaitu sebagai pedoman dalam pembentukan peraturan perundang-undangan di Indonesia. Akan tetapi pengertian dan pemahaman tentang Pancasila menjadi polemik sejak MPR RI pada akhir tahun 2009 membuat program kegiatan sosialisasi empat pilar kehidupan berbangsa dan bernegara yang terdiri atas Pancasila, UUD 1945, NKRI, dan Bhinneka Tunggal Ika.

Gagasan tentang kegiatan sosialisasi empat pilar ini bertujuan sebagai tanggapan atas masih banyak penyelenggara negara dan kelompok masyarakat yang belum memahami dan mengerti tentang nilai-nilai yang terkandung di dalam Pancasila, UUD 1945, NKRI, dan Bhinneka Tunggal Ika serta persoalan kebangsaan pasca reformasi yang datang silih berganti, mulai dari konflik antar etnis, konflik antar partai politik, terorisme, kriminalitas, serta konflik komunal yang berbasis persoalan sosial dan ideologis. Masalah ini telah menyentuh kesadaran para pemimpin negara agar kembali kepada nilainilai kebangsaan yang mulai luntur akibat reformasi tanpa arah dan tujuan (Tim Kerja Sosialisasi MPR-RI, 2012). Kegiatan sosialisasi empat pilar tersebut bertujuan untuk mengingatkan kembali nilai-nilai Pancasila sebagai jati diri dan kepribadian bangsa, UUD 1945 sebagai norma dasar dalam bentuk peraturan perundang-undangan, NKRI sebagai bentuk negara Indonesia, dan Bhinneka Tunggal Ika sebagai ikatan simbolik rasa kebangsaan.
Sejak istilah empat pilar lahir banyak kritik dan komentar bermunculan baik dari kalangan pendidik, pengamat, dosen, maupun kelompok masyarakat lainnya. Penggunaan istilah empat pilar dianggap mengacaukan pengetahuan dan pemahaman masyarakat tentang hakikat, kedudukan, dan fungsi Pancasila sebagai dasar negara karena diletakkan dalam satu varian dan istilah yaitu "pilar". Hal tersebut mengategorikan Pancasila, UUD 1945, NKRI, dan Bhinneka Tunggal Ika sebagai pilar. Pro dan kontra penggunaan istilah empat pilar semakin menguat sejak kelahiran Undang-Undang Nomor 2 Tahun 2011 tentang Perubahan atas Undang-Undang Nomor 2 tahun 2008 tentang Partai Politik pada pasal 34 ayat 3b. Undangundang tersebut menyatakan bahwa "pendidikan politik sebagaimana dimaksud pada ayat (3a) berkaitan dengan kegiatan pendalaman mengenai empat pilar berbangsa dan bernegara yaitu Pancasila, UUD 1945, NKRI, dan Bhinneka Tunggal Ika." Kelompok yang pro terhadap sebutan ini menganggap empat pilar merupakan program yang baik untuk menyosialisasikan kembali nilai-nilai kebangsaan yang sejak reformasi ditinggalkan, sedangkan kelompok yang kontra melihat bahwa empat pilar telah mereduksi hakikat dan kedudukan Pancasila sebagai dasar negara sehingga dapat mengancam pemahaman mendasar dalam pendidikan Pancasila.

Materi Pendidikan Pancasila yang ditulis oleh berbagai penulis buku Pancasila, seperti Notonagoro, Sunoto, Suhadi, Soeprapto, Kaelan, Noor Bakry, dan Suwarno tidak pernah menggunakan istilah empat pilar untuk menyebut Pancasila, UUD 1945, NKRI, dan Bhinneka Tunggal Ika. Akan tetapi sejak istilah empat pilar dipopulerkan oleh MPR RI melalui berbagai bentuk dan model sosialisasi seperti seminar, penulisan buku empat pilar berbangsa dan bernegara yang diterbitkan oleh MPR RI pada 2012, dan lomba cerdas cermat empat pilar bagi pelajar SMA/SMK, pergeseran paradigma pemahaman di dalam pendidikan Pancasila mulai berubah, terutama bagi yang mempercayai dan menganut paradigma empat pilar MPR RI. Terbitnya buku Pancasila dalam Empat Pilar Utama 
Negara Bangsa pada 2011 oleh Pariatra Westra. Kemudian buku tersebut direvisi menjadi Pancasila dalam Empat Konsensus Dasar Kehidupan Negara-Bangsa pada tahun 2015. Terbitnya buku yang mendukung penggunaan istilah empat pilar kehidupan berbangsa dan bernegara secara langsung dan tidak langsung menunjukkan proses pergeseran paradigma dalam membaca dan memahami Pancasila, UUD 1945, Bhinneka Tunggal Ika, dan NKRI mengalami perubahan yang mendasar.

Kaelan (2012) mengawali kritiknya atas empat pilar kehidupan berbangsa dan bernegara dengan menunjukkan bahwa istilah empat pilar mengalami problem fundamental menyangkut sistem epistemologinya. Argumen yang ditunjukkan oleh Kaelan pertama, frasa empat pilar berbangsa kehidupan dan bernegara tidak memenuhi kaidah gramatikal atau tidak lazim. Kedua, menyamakan kedudukan dan fungsi Pancasila, Undang-Undang Dasar 1945, Bhinneka Tunggal Ika, dan Negara Kesatuan Republik Indonesia menjadi suatu varian yang sama. Artinya baik Pancasila, UUD 1945, Bhinneka Tunggal Ika, dan NKRI merupakan unsur yang sama. Ketiga, kekeliruan dalam memahami pengetahuan tentang Pancasila, UUD 1945, Bhinneka Tunggal Ika, dan NKRI yang mencampuradukkan antara nilai, norma, dan praksis terhadap keempat hal tersebut dalam kehidupan masyarakat telah menimbulkan dampak negatif bagi persatuan bangsa Indonesia (Kaelan, 2012, hal. 16-17).

Kondisi bangsa dan negara setelah dua puluh tahun reformasi dinilai tidak menjadi lebih baik meskipun sudah dilakukan sosialisasi empat pilar ala MPR RI. Kondisi berbangsa dan bernegara seakan-akan mengalami kehilangan pedoman dan acuan tentang nilai-nilai hidup bersama. Berbagai persoalan kebangsaan dan politik pada saat awal reformasi, telah terjadi mulai dari krisis ekonomi dan moneter sebagai dampak lanjutan krisis 1998 belum pulih secara total. Berbagai kebijakan politik dan kepemimpinan pada era reformasi mulai dari B.J Habibie, Gusdur, Megawati Soekarnoputri, sampai dengan Susilo Bambang Yudhoyono tampak tidak menunjukkan situasi yang lebih baik.
Polemik tentang Pendidikan Pancasila juga berkembang bersamaan dengan jatuhnya rezim orde baru melalui gerakan reformasi tahun 1998-an. Pertanyaan yang muncul ialah apakah pendidikan Pancasila masih relevan diajarkan di sekolah atau tidak? Sebagai upaya doktrinasi dan ideologisasi masyarakat melalui pendidikan, apakah Pendidikan Pancasila masih perlu dilakukan di tengahtengah alam demokrasi?

Permasalahan ini berkembang dan berimplikasi pada penghapusan mata pelajaran Pancasila di sekolah secara bertahap, seperti perubahan menjadi "Pendidikan Pancasila dan Kewarganegaraan", "Pendidikan Kewarganegaraan", dan akhirnya kembali lagi menjadi "Pendidikan Pancasila dan Kewarganegaraan". Terbitnya UndangUndang Nomor 20 Tahun 2003 tentang Sistem Pendidikan Nasional menjadi dasar yuridis berakhirnya Pendidikan Pancasila. Undang-undang tersebut tidak menyebutkan Pendidikan Pancasila masuk ke dalam kurikulum wajib di sekolah. Dengan demikian, tidak ditemukan lagi Pendidikan Pancasila sebagai mata pelajaran wajib dalam dunia pendidikan. Melihat situasi sosial dan politik yang semakin tanpa arah itu, MPR RI berinisiatif untuk kembali memperkuat nilainilai kebangsaan yang dahulu ditanamkan melalui Pendidikan Pancasila dan P4 sekarang dalam bentuk program sosialisasi.

Berdasarkan latar belakang tersebut, artikel ini bertujuan untuk mendeskripsikan dan menganalisis dampak sosialisasi Empat Pilar MPR RI terhadap pemahaman Pancasila di perguruan tinggi dan untuk memberikan pemahaman pada masyarakat terkait dengan pentingnya memahami Pancasila secara benar. Pertanyaan penelitian ini dikhususkan pada dampak konteks materi dan bahan ajar pendidikan Pancasila, cara pandang atau paradigma pemahaman dosen dan mahasiswa dalam memahami Pancasila sebagai dasar atau sebagai pilar, dan aspek kepastian dalam menjelaskan kedudukan Pancasila, UUD 1945, NKRI, dan Bhinneka Tunggal Ika.

\section{Metode}

Penelitian ini merupakan penelitian deskriptif dengan pendekatan metode 
kualitatif melalui kajian kepustakaan. Adapun pengumpulan data dilakukan melalui kajian pustaka berupa buku, jurnal ilmiah, hasil penelitian, dokumen yuridis seperti peraturan perundang-undangan, artikel pada surat kabar, dan berita baik online maupun offline dengan teknik kategorisasi data, reduksi data, dan verifikasi data. Setelah itu, data penelitian dianalisis dengan menggunakan metode analisis interpretasi, induksi-analitis, semiotik, dan analisis wacana.

\section{Hasil dan Pembahasan Dasar-dasar dan Tujuan Pendidikan Pancasila}

Dasar pemikiran tentang pentingnya Pendidikan Pancasila diberikan kepada masyarakat khususnya generasi muda di dunia pendidikan bertitik tolak pada konsepsi dan pengertian dasar pendidikan Pancasila. Wreksosuhardjo (2004, hal. 12) menyatakan bahwa "Pendidikan Pancasila adalah pendidikan mengenai filsafat hidup bangsa Indonesia, dasar filsafat (asas kerohanian) dan ideologi negara RI." Pengertian lain juga menjelaskan bahwa "Pendidikan Pancasila merupakan proses pembudayaan atau pewarisan budaya luhur bangsa dari generasi tua kepada generasi muda" (Winarno, 2012, hal. 8). Pengertian tersebut menjadi acuan dalam mengembangkan pendidikan Pancasila di perguruan tinggi. Paradigma pendidikan di Indonesia melalui kurikulum 2013 juga menekankan capaian pembelajaran menyangkut aspek sikap, pengetahuan, dan keterampilan (Sutarto, Jaedun, \& Nuryadin, 2017, hal. 45). Pendidikan Pancasila bertujuan untuk mengarahkan peserta didik menuju capaian pembelajaran dalam upaya pembentukan karakter kebangsaan. Kementerian Riset, Teknologi, dan Pendidikan Tinggi menjelaskan bahwa "tujuan mata kuliah pendidikan Pancasila di perguruan tinggi diarahkan untuk lebih fokus dalam membina pemahaman dan penghayatan mahasiswa mengenai ideologi bangsa Indonesia" (Kementerian Riset Teknologi dan Pendidikan Tinggi, 2016). Pendidikan Pancasila memiliki dasar dan tujuan yang strategis dan sistematis dalam rangka membangun pemahaman dan penghayatan mahasiswa mengenai nilai-nilai dasar kehidupan berbangsa dan bernegara. Sejalan dengan politik pendidikan di Indonesia bahwa politik pendidikan Indonesia harus berpijak pada bumi dan budaya nusantara yang mengacu pada ideologi Pancasila, Konstitusi UUD 45, persatuan dan kesatuan NKRI, Bhinneka Tunggal Ika, kekayaan, karakteristik, dan kebutuhan Indonesia.

Pendidikan Pancasila secara sistematis di Indonesia memiliki 4 dasar. Pertama, dasar historis. Perjalanan bangsa Indonesia merupakan proses panjang yang pada suatu titik tersimpul nilai-nilai, filosofi, dan pandangan hidup bangsa yang menjadi ciri khas, karakter, dan identitas nasional. Hal ini kemudian dikristalisasi ke dalam nilai-nilai Pancasila. Dasar historis sejarah bangsa Indonesia tersebut menjadi alasan rasional perlunya Pendidikan Pancasila di perguruan tinggi agar memahami sejarah bangsanya. Dengan begitu, generasi muda siap menerima estafet kepemimpinan selanjutnya (Kaelan, 2014; Wreksosuhardjo, 2004).

Kedua, dasar kultural. Kebudayaan merupakan warisan sosial 'the social inheritance' dari generasi sebelumnya sehingga kebudayaan menjadi modal dasar dalam membangun peradaban untuk membuat hidup lebih bertata krama serta lebih meninggikan harkat dan martabat manusia (Wreksosuhardjo, 2004, hal. 15). Pada dasarnya setiap bangsa memiliki suatu pandangan hidup, filosofi hidup, dan pegangan hidup yang diekspresikan dalam kebudayaan seperti bahasa, adat istiadat, tarian, tata cara hidup, pola pikir, dan cita-cita hidup. Indonesia telah mendasarkan pandangan hidupnya dalam bermasyarakat, berbangsa, dan bernegara pada asas kebudayaan yang dimiliki dan melekat pada bangsa sendiri (Kaelan, 2014, hal. 4). Oleh karena itu para penerus bangsa terutama kalangan intelektual kampus sudah seharusnya mendalami dan mempelajari secara dinamis arti kebudayaan bangsa.

Ketiga, dasar filosofis. Pancasila merupakan dasar filsafat negara dan pandangan filosofis bangsa Indonesia. Oleh karena itu nilai-nilai yang terdapat di dalam sila-sila Pancasila perlu dipelajari dan dipahami sebagai sumber nilai dalam 
pelaksanaan dan pembangunan nasional, ekonomi, politik, hukum, sosial, maupun pertahanan dan keamanan (Kaelan, 2014, hal. 5-6). Hal ini sejalan dengan pendapat As'ad (2009, hal. 51) bahwa "Pancasila adalah dasar resmi kebangsaan dan kenegaraan... Pancasila adalah milik semua warga negara" Oleh karena itu amatlah layak dan penting mempelajari Pancasila secara terus menerus.

Keempat, dasar yuridis. Undang-Undang Nomor 12 tahun 2012 tentang Pendidikan Tinggi pasal 35 ayat (3) secara eksplisit mencantumkan pendidikan Pancasila sebagai kurikulum wajib di Perguruan Tinggi (Kaelan, 2014, hal. 4). Dasar yuridis ini menjadi acuan bagi perguruan tinggi untuk melaksanakan Pendidikan Pancasila. Pelaksanaan Pendidikan Pancasila tidak sekadar memiliki dasar, namun juga bertujuan agar peserta didik memahami filosofi bangsanya dan nilai-nilai kehidupan melalui pembelajaran sejarah dan hakikat Pancasila dalam bermasyarakat, berbangsa, dan bernegara.

\section{Pentingnya Pendidikan Karakter Pancasila}

Pancasila adalah fondasi negara dan cara hidup bangsa. Dengan demikian studi tentang pelaksanaan Pancasila melalui pembelajaran Pendidikan Kewarganegaraan menjadi penting. Ada beberapa alasan, pertama, Pancasila adalah sistematika nilai yang membutuhkan penerapannya di kehidupan sehari-hari. Kedua, implementasi Pancasila bisa dilakukan melalui berbagai cara salah satunya melalui pendidikan. Ketiga, isi Pancasila yang disosialisasikan kepada warga negara dapat digunakan untuk mendirikan nasional identitas. Keempat, isi Pancasila dalam Bahasa Indonesia dan Pendidikan Kewarganegaraan masih menghadapi kelemahan dalam hal metode pembelajaran. Kelima, Pancasila yang memiliki berbagai status, makna dan interpretasi membutuhkan struktur dan organisasi yang jelas sebagai bahan pendidikan kewarganegaraan (Supeni, 2015, hal. 124).

Sila-sila Pancasila dalam pelaksanaan pendidikan diperlukan untuk pengembangan kognitif yang mengarah pada pencapaian kecerdasan logika dan kecerdasan visual spasial pada sila Pertama. Anak-anak dibimbing berdoa sebelum mulai pelajaran, sebelum makan dan diajarkan bagaimana cara beribadah dengan baik dan benar. Sila kedua dan ketiga meliputi pengembangan perasaan dan emosi serta pengembangan kemampuan sosial/sosialisasi dan peningkatan kepekaan terhadap kehidupan bermasyarakat. Pengembangan ini mengarah pada pencapaian kecerdasan interpersonal, kecerdasan interpersonal dan naturalistis. Sila keempat dan kelima mengarah pada pencapaian kecerdasan linguistik. Contohnya anak-anak dapat belajar berkomunikasi dan bermusyawarah dengan teman-temannya, menyebutkan nama-nama pulau, keBhinekaan dan keragaman suku bangsa, agama dan kepercayaan yang dianut bangsa Indonesia, dan kesetiakawanan sosial (Supeni, 2015, hal. 125)

Pendidikan Pancasila berdasarkan kearifan lokal adalah model atau strategi pendidikan yang memiliki relevansi yang penting untuk pengembangan keterampilan hidup dengan fokus pada pemberdayaan keterampilan dan potensi lokal di setiap wilayah. Materi pembelajaran Pancasila memiliki makna yang relevan dengan pemberdayaan masyarakat berdasarkan kenyataan yang mereka hadapi dalam kehidupan sehari-hari. Kurikulum dalam pendidikan Pancasila disusun sesuai dengan kondisi lingkungan, minat pelajar, kondisi pelajar, dan perhatian pada aspek sosiologis dan budaya.

Pendidikan Pancasila yang berbasis pada kearifan lokal adalah pendidikan yang mengajarkan peserta didik untuk merangkul situasi konkrit yang mereka hadapi dalam kehidupan sehari-hari. Salah satu hasil dari pendidikan berbasis pada kearifan lokal bisa dalam bentuk pengetahuan yang menggambarkan sikap dan perilaku yang mencerminkan budaya asli lokal dan nilainilai Pancasila. Dalam kasus Surakarta, budaya asli lokal adalah budaya Jawa. Nilainilai kebijaksanaan budaya Jawa seperti gotong royong atau gotong royong, tepo seliro atau toleransi, dan solidaritas adalah nilainilai yang baik yang seharusnya disampaikan kepada siswa di sekolah. Budaya Jawa adalah 
sumber moral kewarganegaraan. Di sebuah negara-bangsa, aturan yang mengikat kuat dalam bentuk moral kewarganegaraan dibutuhkan, selain dari hak dasar warga negara.

Moral kewarganegaraan adalah pedoman hidup warga, yang bisa membantu warga untuk menilai tindakan yang benar atau salah. Tanpa niat untuk merusak peran komunitas budaya etnis lain itu mendukung keragaman dalam kesatuan Indonesia, budaya Jawa dan nilai-nilai moralnya menarik untuk dipelajari. Misalnya, idiom 'Ojo dumeh' yang dapat berarti bahwa orang-orang seharusnya tidak sombong meski memiliki yang tinggi posisi. Selain itu juga dapat menjadi sumber moral warga negara. Penggalian budaya Jawa bertujuan untuk membuktikan bahwa ada nilai-nilai universal di dalam budaya Jawa yang bisa diterima secara komprehensif oleh orang Indonesia dan bertindak sebagai strategi untuk mencapai tujuan pembelajaran nilainilai kebangsaan (Sumardjoko \& Musyiam, 2018). Pendidikan Pancasila menjadi alat yang strategis untuk membangun identitas dan karakter bangsa Indonesia. Berdasarkan uraian di atas, revitalisasi pembelajaran pendidikan Pancasila di Indonesia sesuai dengan tuntutan dan kebutuhan pengembangan identitas nasional dan karakter perlu dilakukan. Salah satunya strategi adalah melalui pengembangan pembelajaran pendidikan Pancasila berdasarkan pada kearifan lokal.

Efektivitas model pembelajaran pendidikan Pancasila berdasarkan kearifan lokal sebagai strategi untuk merevitalisasi nilai-nilai Pancasila untuk memperkuat karakter dan identitas bangsa. Pendidikan karakter berbasis Pancasila sebagai alat belajar yang sesuai untuk siswa mengembangkan nilai-nilai moral Pancasila yang sesuai dengan bangsa dan negara (Murdiono, Miftahuddin, \& Kuncorowati, 2017, hal. 427). Pancasila juga mempunyai semangat kekeluargaan dan gotong-royong. Makna gotong-royong dan kekeluargaan selalu ditemukan dalam setiap zaman. Artinya, makna itu selalu diinterprestasi dalam hidup konkret di setiap zaman dan setiap waktu. Hidup bergotong-royong dan kekeluargaan bukanlah hidup seperti masa lalu tetapi perlu aktualisasi sesuai dengan situasi hidup konkret (Sudaryanto, 2017).

Pancasila sebagai titik pijak dalam usaha pengembangan ilmu, memungkinkan ilmuwan tidak sekadar meletakkan pada pendirian "ilmu untuk ilmu" (science for the sake of science) akan tetapi berpendirian yang teleologis yaitu mementingkan penggunaan (penerapan) ilmu untuk kebaikan hidup kemanusiaan, dengan tetap memelihara tugas ilmu yang langsung dan murni, yaitu mencapai kenyataan dan kebenaran. Sebelum ilmu itu diterapkan dapat dikatakan bebas dari nilai (free of values) artinya ilmu itu tidak dapat dikenai penilaian baik atau buruk, bermoral atau tidak bermoral. Dalam hal ini, bidang ilmu adalah amoralitas (amorality), artinya tidak tercakup dalam bidang moral dan immoral. Ilmu di luar penilaian bermoral atau tidak bermoral. Namun apabila ilmu itu diterapkan atau diaplikasikan dalam kehidupan berarti secara mutlak terkenai penilaian moral dan tidak bermoral karena penerapan ilmu akan melibatkan kehidupan manusia. Selanjutnya Pancasila dapat menjadi pokok pangkal sudut pandangan dalam teori mengenal (kriteriologi), asas sebab-akibat dan dalam hal hubungan antara ilmu dan moral. Manusia dengan akalnya dapat memperoleh pengetahuan tentang keadaan yang senyatanya (Mudhofir, 2006, hal. 33).

\section{Materi Pendidikan Pancasila}

Materi pendidikan Pancasila memiliki beberapa periode perkembangan dan perubahan. Pada periode awal, di perguruan tinggi pada 1960-an Notonagoro memperkenalkan Pancasila dengan nama Filsafat Pancasila. Materi Pancasila banyak digali dari muatan sila-sila Pancasila pada pembukaan UUD 1945, UUD 1945, dan gagasan pengajaran Filsafat Pancasila kepada mahasiswa di Perguruan Tinggi. Istilah Filsafat Pancasila menjadi populer di kalangan mahasiswa pada waktu itu. Pada masa pemerintahan Soeharto menerbitkan Ketetapan MPR No.II/MPR/1978 tentang Pedoman Penghayatan dan Pengamalan Pancasila (Ekaprasetia Pancakarsa). Pendidikan Pancasila mulai diajarkan secara sistematis dan memiliki kandungan materi 
yang lebih banyak dengan berdirinya BP7 (Badan Pembinaan Pendidikan Pelaksanaan Pedoman Penghayatan dan Pengamalan Pancasila) pada 1979 melalui Keputusan Presiden Nomor 10 tahun 1979 tentang Badan Pembinaan Pendidikan Pelaksanaan Pedoman Penghayatan dan Pengamalan Pancasila.

Pada masa itu istilah "Pendidikan Pancasila" belum dikenal, namun lebih populer "kuliah Filsafat Pancasila", "kuliah Pancasila" atau "kuliah P4". Berbagai bahan ajar yang diterbitkan masih dalam bentuk sederhana seperti diktat kuliah yang dibuat oleh dosen pengampu, buku yang diterbitkan oleh BP7, dan buku Pancasila: Secara Ilmiah Populer karya Notonagoro.

Muatan materi Pancasila yang diajarkan di Perguruan Tinggi pada periode awal lebih terfokus pada pemahaman Pancasila dari sudut pandang filsafat. Kemudian materi berkembang dengan terbitnya Ketetapan MPR No II/MPR/1978 dan Keppres No 10/1979 tentang BP7. Arah dan orientasi materi Pancasila dituntun untuk mendalami 36 butirbutir Pancasila, UUD 1945, Garis-Garis Besar Haluan Negara (GBHN), dan pengembangan Pancasila secara yuridis kenegaraan. Sedangkan pada tingkat pendidikan dasar dan menengah materi Pancasila dikenal dengan istilah Pendidikan Moral Pancasila (PMP).

Pada periode setelah reformasi bersamaan dengan lengsernya Soeharto, dinamika dan perkembangan materi pendidikan Pancasila cenderung bervariasi dan beragam. Hal ini disesuaikan dengan tuntutan dan perubahan peraturan yang mengatur materi dan mata pelajaran Pendidikan Pancasila. Pada periode reformasi, istilah "Pendidikan Pancasila" mulai populer dan dikenal. Berbagai penulis mulai bermunculan pada era ini karena BP7 dibubarkan. Muatan materi Pancasila juga mengalami penyesuaian dan penambahan. Kasus ini juga terjadi dalam konteks pembelajaran kewarganegaraan di Indonesia dinilai masih terjadi ketimpangan baik dari aspek struktur kurikulum dan pengajaran di kelas. Meskipun aspek pengetahuan kewarganegaraan lebih banyak diajarkan di kelas, namun tidak menjamin pengetahuan kewarganegaraan siswa lebih tinggi (Mulyoto \& Samsuri, 2017, hal. 106).

Sekalipun demikian, ada penulis yang tetap konsisten menerbitkan buku tentang Pancasila dengan penambahan subbab terkait konteks reformasi, seperti HAM, hukum dan konstitusi, serta sistem politik Indonesia. Pada konteks reformasi, materi Pancasila memiliki porsi lebih kecil dan lebih sedikit akibat adanya perubahan peraturan perundangundangan. Pada 2003 silam, perubahan peraturan perundang-undangan mengganti mata kuliah "Pancasila" menjadi "Pendidikan Kewarganegaraan". Kemudian, pada 2012 melalui UU No.12/2012 tentang Pendidikan Tinggi, mata kuliah Pancasila dihadirkan kembali, baik secara eksplisit maupun implisit. Secara eksplisit, mata kuliah tentang dasar negara tersebut muncul kembali dengan nama "Pendidikan Pancasila" atau "Pendidikan Pancasila dan Kewarganegaraan". Sementara itu, secara implisit Pancasila hadir lebih sedikit melalui sub bab dalam mata kuliah "Pendidikan Kewarganegaraan". Adapun metode yang dipakai juga cukup variatif dan tidak terbatas di ruang kelas, seperti diskusi, studi lapangan, bermain peran, presentasi, dan ceramah. Secara umum, buku-buku tentang Pancasila yang terbit di era 1970-an sampai 2006 masih konsisten mengungkap sejarah Pancasila sebagai dasar negara dan penjabaran nilainilai Pancasila dalam berbagai aspek kehidupan, termasuk aktualisasinya.

Direktorat Jenderal Pembelajaran dan Kemahasiswaan Kemenristek dan Dikti mengeluarkan buku Ajar mata kuliah wajib umum Pendidikan Pancasila bagi Perguruan Tinggi tahun 2016 yang terdiri atas tujuh bab. Bab pertama, membahas latar belakang pendidikan Pancasila, kebijakan nasional pembangunan bangsa dan karakter; landasan hukum pendidikan Pancasila; kerangka konseptual pendidikan Pancasila; visi dan misi; tujuan pendidikan Pancasila; kerangka konseptual pendidikan Pancasila; visi dan misi; tujuan pendidikan Pancasila; desain mata kuliah, kompetensi inti dan kompetensi dasar. Bab kedua, membahas Pancasila dalam sejarah bangsa Indonesia. Bab ketiga, membahas kedudukan Pancasila sebagai dasar 
negara. Bab keempat, membahas kedudukan Pancasila sebagai ideologi negara. Bab kelima, mengkaji pengertian filsafat, filsafat Pancasila, hakikat sila-sila Pancasila. Bab keenam, Pancasila dikaji sebagai sistem etika. Bab ketujuh, membahas dan mengkaji Pancasila sebagai dasar nilai pengembangan ilmu. Berbagai materi yang ada dan berkembang tentang Pancasila telah menjelaskan bahwa Pancasila tetap memiliki kedudukan sebagai dasar negara.

\section{Persoalan Sosialisasi Empat Pilar MPR RI}

Sosialisasi empat pilar MPR RI memiliki persoalan mendasar yaitu bertentangan dengan sejarah bangsa Indonesia. Oleh karena itu pelurusan penggunaan istilah empat pilar oleh MPR RI sangat mendesak dan penting karena apabila dibiarkan kegiatan itu akan menghapus memori kolektif generasi muda bangsa tentang hakikat dan kedudukan Pancasila, UUD 1945, NKRI, dan Bhinneka Tunggal Ika yang sebenarnya. Dalam tatanan bernegara dan bermasyarakat, yang paling mendasar ialah aspek kepatuhan dan konsisten terhadap norma-norma yang telah disepakati. Pancasila merupakan nilai-nilai yang telah disepakati oleh para pendiri bangsa ini sebagai dasar negara dan filosofi hidup bangsa. Kepatuhan dan konsistensi terhadap norma-norma ini menjadi penting dalam kehidupan bermasyarakat, berbangsa, dan bernegara. Peran elite dan pemerintah untuk menjaga dan mengawal masyarakat dalam segala aspek kehidupan yang ada di sekitarnya sangat penting demi memastikan laju gerak pemerintah sesuai dengan nilai-nilai yang telah disepakati bersama.

Nalar negara pasca reformasi ini menunjukkan bahwa nalar para elite kini mengarah pada suatu nalar kekuasaan. Negara Indonesia saat ini menunjukkan suatu gejala negara tanpa bentuk. Hal ini dapat dilihat dari proses pengambilan kebijakan pemerintah untuk kepentingan publik, termasuk pendidikan, yang dilakukan tanpa dasar dan orientasi yang jelas. Praktik-praktik bernegara justru tidak pernah menunjukkan relasi kausalitas terhadap upaya normatif dan etis dari penyelenggara negara untuk menyelamatkan dan mengarahkan pada citacita dan tujuan bernegara, sebagaimana terdapat dalam pembukaan UUD 1945 menjadi negara yang merdeka, bersatu, berdaulat, adil dan makmur sesuai dengan dasar nilai Pancasila. Sosialisasi Empat Pilar merupakan bentuk buruk model sosialisasi nilai-nilai kebangsaan pasca reformasi ini.

Keberadaan empat pilar berbangsa dan bernegara yang terdiri atas Pancasila, UUD 19445, NKRI, dan Bhinneka Tunggal Ika oleh MPR RI sejak akhir 2009 itu telah menimbulkan persoalan dalam proses belajar mengajar pendidikan Pancasila di dunia pendidikan, khususnya perguruan tinggi. Empat pilar tersebut menjadi paradigma baru dan sudah diterima sebagai suatu kebenaran dalam menanamkan nilai-nilai kebangsaan bagi intelektual muda di kampus. Banyak akademisi dan mahasiswa mulai menerima dan percaya bahwa Pancasila, UUD 1945, NKRI, dan Bhinneka Tunggal Ika adalah pilar-pilar kebangsaan. MPR RI tampak gencar menyosialisasikan paham ini lewat berbagai kegiatan dan media massa. Sepanjang 2009 hingga 2018 saat ini, telah diadakan bincang-bincang, lomba cerdas cermat, diskusi publik, seminar, dan pelatihan terkait empat pilar di berbagai daerah, mulai dari tingkat desa sampai dengan perguruan tinggi. Kegiatan ini dilakukan tanpa mempertimbangkan aspek potensi ancaman dan persoalan di kemudian hari. Mengategorikan Pancasila, UUD 1945, NKRI, dan Bhinneka Tunggal Ika sebagai empat pilar merupakan kesalahan fatal.

Buku terbitan MPR RI yang dibagibagikan secara gratis kepada seluruh peserta sosialisasi pada 2012 lalu telah menghancurkan fondasi pemahaman generasi muda dan masyarakat selama ini tentang makna dan kedudukan Pancasila, UUD 1945, NKRI, dan Bhinneka Tunggal Ika yang sebenarnya. Akibatnya, pemahaman tentang Pancasila mengalami perubahan secara masif, struktural, dan sistematis, khususnya untuk pendidikan Pancasila di perguruan tinggi. Perubahan tersebut dapat dilihat dari aspek materi pendidikan Pancasila, cara pandang, dan metode pengajaran. Pada aspek materi, saat ini ditemukan dua buku acuan tentang pendidikan Pancasila. Buku itu secara eksplisit memuat Empat Pilar pada 
sampulnya. Buku pertama ditulis oleh dengan judul Empat Pilar Berbangsa dan Bernegara Pancasila-UUD 9145-Negara Kesatuan RIBhinneka Tunggal Ika (dalam rangka Mata Pelajaran Pendidikan Pancasila, Pendidikan Kewarganegaraan serta penataran Masyarakat) pada tahun 2011. Dalam buku tersebut, terdapat empat bagian yang dibahas, yaitu Pancasila, UUD 9145, NKRI, dan Bhinneka Tunggal Ika. Bagian-bagian ini mengikuti alur pemikiran MPR RI.

Buku kedua bertajuk Indonesia Baru Empat Konsensus Satu Dasar Berbangsa dan Bernegara Indonesia (Pancasila, Proklamasi Kemerdekaan, UUD 1945, NKRI, dan Bhinneka Tunggal Ika). Dalam buku karya Tukiran Taniredja, dkk. (2015) tersebut tidak dijabarkan gagasan alasan dan dasar pemilihan judul. Di dalam pengantar juga tidak ada penjelasan tentang "satu dasar" dan tentang "empat konsensus". Buku acuan ini dibagi menjadi lima bab. Bab I membahas Pancasila. Bab II menjelaskan UUD 1945. Setelah itu, NKRI diuraikan dalam bab III. Bab IV membicarakan Bhinneka Tunggal Ika. Terakhir, bab V mengupas proklamasi kemerdekaan. Substansi buku ini lahir dari proses pemahaman Empat Pilar MPR RI yang dikembangkan secara inovatif. Meskipun demikian, dalam buku ini tidak dijabarkan alasan memasukkan Proklamasi Kemerdekaan sebagai bagian dari konsepsi pelengkap empat konsensus dasar.

Cara pandang memahami Pancasila dan Pendidikan Pancasila dari sebelum dan sesudah kemunculan Empat Pilar MPR RI menunjukkan sistematika yang lebih sempit. Nilai-nilai kebangsaan atau bangunan suatu negara hanya sekadar dilihat dari empat pilar, yakni Pancasila, UUD 1945, NKRI, dan Bhinneka Tunggal Ika. Kaelan (2012) mengkritisi penggunaan istilah Empat Pilar Berbangsa dan Bernegara sebagai salah satu bentuk kesalahan epistemologi (epistemological mistake) karena mengategorikan empat hal tersebut sebagai pilar. Para akademisi melalui berbagai media mengatakan bahwa frasa empat pilar berbangsa dan bernegara telah meresahkan masyarakat akademik karena tidak sejalan dengan sejarah berdirinya bangsa dan sejarah
Pancasila. Kaum intelektual ini tidak pernah mengenal pilar untuk menyebut Pancasila, UUD 1945, NKRI, dan Bhinneka Tunggal Ika. Penyebutan Pancasila, UUD 1945, NKRI, dan Bhinneka Tunggal Ika sebagai pilar adalah sesat pikir.

Penggunaan istilah empat pilar pada dasarnya, tidak memiliki rujukan ilmiah yang jelas. Alasan pertama, Pancasila dalam sejarah pembentukan dasar negara tidak pernah dikenal sebagai pilar. Kedua, UUD 1945 yang lahir dan ditetapkan bersamaan dengan Pancasila juga tidak pernah disebut sebagai pilar, tetapi sebagai hukum dasar atau norma dasar negara. Ketiga, NKRI, dalam UUD 1945 Pasal 1 ayat 1, dinyatakan bahwa Negara Indonesia ialah Negara Kesatuan, yang berbentuk Republik. Sampai sejauh ini belum ada dokumen yuridis dan historis sejak berdirinya negara Indonesia NKRI disebut sebagai pilar, kecuali pernyataan MPR RI yang sudah dianulir oleh putusan MK Nomor 100/PUU-XI/2013.

Mahkamah berpendapat, dalam uji materi UU No.2/2011 tentang Partai Politik-perkara No.100/PUU-XI/2013, bahwa apabila Pancasila ditempatkan sebagai salah satu pilar, selain kedudukan sama dan sederajat dengan pilar yang lain, hal ini akan menimbulkan kekacauan epistemologis, ontologis, dan aksiologis. Pancasila memiliki kedudukan tersendiri dalam kerangka berpikir bangsa dan negara Indonesia berdasarkan konstitusi. Alasan keempat, dalam UUD 1945 pasal 36A disebutkan Lambang Negara ialah Garuda Pancasila dengan semboyan Bhinneka Tunggal Ika. UUD 1945 dengan jelas disebutkan norma dasar negara dan Bhinneka Tunggal Ika ialah semboyan. Pasca putusan Mahkamah Konstitusi Nomor 100/PUU$\mathrm{XI} / 2013$ tentang perkara pengujian materiel terhadap Undang-Undang Nomor 2 Tahun 2011 tentang Perubahan Atas UndangUndang Nomor 2 Tahun 2008 tentang Partai Politik terhadap Undang-Undang Dasar Negara Republik Indonesia Tahun 1945 bahwa frasa empat pilar berbangsa dan bernegara tidak mempunyai kekuatan hukum mengikat.

Putusan Mahkamah Konstitusi tersebut telah memberikan penegasan dan kepastian 
hukum bahwa Pancasila tidak dapat disejajarkan atau disamakan dengan pilar dalam bentuk peraturan perundang-undangan karena telah bertentangan dengan prinsip dan asas kepastian hukum terhadap kedudukan dan fungsi Pancasila dalam kehidupan berbangsa dan bernegara. Beberapa akademisi, seperti Kansil dan Kansil telah terpengaruh dengan konsep empat pilar MPR RI dengan menerbitkan tulisan berjudul Empat Pilar Berbangsa dan Bernegara pada tahun 2011.

Begitu pula Kresna dan Suhendra pada tahun 2016 merujuk istilah empat pilar dalam buku yang ditulis untuk mahasiswa Pendidikan Pancasila atau Pendidikan Pancasila dan Kewarganegaraan (PPkn). Hal ini terbaca dari pembahasan dalam bab kedua tentang Identitas Nasional pada halaman 23, bahwa integrasi nasional tetap bertitik tolak pada pemahaman 4 pilar kebangsaan yaitu Pancasila, UUD 1945, NKRI, dan Bhinneka Tunggal Ika. Dalam jurnal berjudul "Multikulturalisme dalam Perspektif Empat Pilar Kebangsaan", Sudharto menyebutkan bahwa Empat pilar, yakni Pancasila, UUD 1945, NKRI, dan Bhinneka Tunggal Ika, telah memberikan landasan pemahaman terkait multikulturalisme. Tim dosen Pancasila Pusat MPK Universitas Brawijaya tampak menolak istilah Empat Pilar. Melalui buku Pancasila dalam Diskursus Sejarah, Jalan Tengah, dan Filosofi Bangsa, para akademisi tersebut menunjukkan bahwa Empat Pilar yang digunakan oleh MPR RI telah memosisikan Pancasila dengan kurang tepat sehingga menjadi bermasalah (Tim Dosen Pancasila Pusat MPK Universitas Brawijaya, 2017). MPR RI pasca putusan Mahkamah Konstitusi tersebut sampai sekarang tidak bersedia melakukan revisi dan perbaikan atas kesalahan penggunaan istilah itu. Di berbagai kegiatan sosialisasi, istilah empat pilar MPR RI yang terdiri atas Pancasila, UUD 1945, NKRI, dan Bhinneka Tunggal Ika tetap digunakan.

Airlangga (2017) mengkritisi program sosialisasi empat pilar MPR RI dari dua aspek penting. Pertama, menempatkan Pancasila sebagai pilar merupakan kesalahan fatal sebab dalam pembukaan UUD 1945, Pancasila sebagai dasar negara telah disepakati oleh para pendiri bangsa (philosophische grondslag). Kedua, pada dasarnya sosialisasi empat pilar MPR RI tidak ada urusannya dengan tugas dan wewenang MPR RI.

Peran Pendidikan Pancasila sebagai bagian dari upaya memperkuat nilai-nilai kebangsaan semakin direduksi oleh MPR RI karena program sosialisasinya justru berdampak pada kesalahan pemahaman mengenai Pancasila dan nilai-nilai kebangsaan. Materi pendidikan Pancasila dirumuskan dan dikembangkan dalam waktu dan proses yang cukup panjang, mulai dari aspek sejarah, filosofi, yuridis, kultural, dan sosiologis. Materi Pancasila memberikan ruang yang luas untuk membangun pemikiran tentang kebangsaan melalui berbagai unsur dan nilai yang terlibat dalam proses pembentukan karakter dan jati diri bangsa. Sejarah pembentukan negara bangsa Indonesia tidak dapat terlepas dari berbagai kondisi sosial dan politik serta dinamika kehidupan masyarakat. Model sosialisasi empat pilar MPR RI yang dilakukan tanpa arah dan tujuan yang jelas telah membawa paradigma pendidikan Pancasila ke arah yang kurang pasti. Metode pendidikan Pancasila pasca reformasi, yang selama ini hendak meluruskan sejarah Pancasila sebagai dasar negara yang benar dalam semua aspek kehidupan, menjadi terganggu akibat MPR RI menyebut Pancasila sebagai pilar, UUD 1945 sebagai pilar, NKRI sebagai pilar, dan Bhinneka Tunggal Ika sebagai pilar.

Pertentangan nilai dan wacana tentang kedudukan dan fungsi Pancasila akan kembali terus dipertanyakan. Di satu sisi, Pancasila sebagai dasar negara merupakan fakta sejarah. Namun di sisi lain, MPR RI meletakkan pemikiran dan gagasannya bahwa negara bangsa ini didirikan hanya atas dasar pilar, padahal pilar tersebut sebenarnya sudah pernah ada. Pembuatan rumusan istilah Empat Pilar yang mengategorikan Pancasila, UUD 1945, NKRI, dan Bhinneka Tunggal Ika merupakan cerminan penalaran elite negara yang sudah tidak memiliki dasar-dasar etis dan akal sehat dalam meletakkan sendi-sendi bernegara yang baik dan benar. Norma-norma dilanggar hanya untuk memenuhi kepentingan 
politik anggaran dan kebutuhan pragmatis sebagai proyek sesaat. Istilah Empat Pilar yang disosialisasikan secara terus menerus telah menimbulkan ketidakpastian pemaknaan dan identitas mengenai Pancasila, UUD 1945, NKRI, dan Bhinneka Tunggal Ika.

\section{Dampak Sosialisasi Empat Pilar MPR RI}

Istilah yang dikategorikan oleh MPR RI sebagai empat pilar telah berdampak pada interpretasi dan pemahaman berbagai macam di masyarakat tentang kebenaran dan nilainilai yang dipegang dalam Pancasila. Interpretasi dan pemahaman atas Pancasila dalam kehidupan berbangsa dan bernegara yang berbeda akan menimbulkan suatu pertentangan teoretis dan konseptual nilai mana yang harus dianut. Edelman menjelaskan bahwa bahasa merupakan kreator kunci (key creator) dalam pembentukan pengalaman manusia di kehidupan sosial (Edelman, 1985). Istilah "empat pilar" apabila semakin sering dipopulerkan akan menjadi kreator kunci dalam membentuk pengalaman manusia Indonesia di kehidupan sosial bahwa Pancasila, UUDNRI Tahun 1945, NKRI, dan Bhinneka Tunggal Ika semuanya terangkum dalam kategori empat pilar.

Model sosialisasi semacam ini akan berpotensi pada ancaman manipulasi pengetahuan kepada peserta didik atau masyarakat. Istilah empat pilar yang terdiri dari Pancasila, UUDNRI Tahun 1945, NKRI, dan Bhinneka Tunggal Ika melalui sosialisasi yang dilakukan oleh MPR RI justru dianggap merupakan model yang buruk untuk memberikan atau menanamkan nilai-nilai kebangsaan, persatuan dan kesatuan, kesadaran berbangsa dan bernegara karena secara konseptual empat pilar sudah menimbulkan polemik dan pertentangan. Empat Pilar Kehidupan Berbangsa dan Bernegara yang bertujuan untuk memberikan pengertian, pendidikan, dan pengarahan kepada masyarakat tentang pentingnya kehidupan berbangsa dan bernegara sudah tidak dapat diterima sebagai pendidikan yang bernilai.

Empat Pilar Kehidupan Berbangsa dan Bernegara telah berimplikasi secara teoretis di bidang pendidikan terutama pada aspek materi dan bahan ajar. Materi tentang Pancasila sebagai pilar, UUD 1945 sebagai pilar, NKRI sebagai pilar, Bhinneka Tunggal Ika sebagai pilar tidak dikenal dalam sejarah dan materi pendidikan ideologi atau Pancasila di Indonesia. Akibatnya di dunia pendidikan, telah terjadi kesalahan dalam memahami Pancasila sebagaimana yang telah dilakukan oleh Konsorsium PTN se-kawasan timur Indonesia ketika mendeklarasikan sikap kebangsaannya, sebanyak 29 PTN yang tergabung dalam konsorsium tersebut menyatakan bersikap memegang teguh empat pilar kebangsaan, yakni Pancasila, UUD NRI Tahun 1945, NKRI, dan Bhinneka Tunggal Ika. Deklarasi ini disaksikan Menteri Riset, Teknologi, dan Pendidikan Tinggi, Mohammad Nasir (lihat kompas, Sabtu,17/06/2017, hal.12, "sebanyak 29 PTN Deklarasi Sikap Kebangsaan”). Apabila konsep ini tetap diproduksi dan disosialisasikan oleh lembaga negara di ruang sosial akan berdampak pada hilangnya memori kolektif bangsa dalam memahami sejarah yang benar dan fungsi serta kedudukan Pancasila dalam hubungannya dengan sistem tata negara di Indonesia.

Materi sosialisasi yang dibuat oleh MPR RI pada dasarnya sudah terangkum dalam pendidikan Pancasila dan kewarganegaraan sehingga tidak perlu lagi untuk dilakukan dalam bentuk nama baru. Dampak yang telah nyata sejak adanya sosialisasi empat pilar menjadikan para pendidik secara khusus para dosen di perguruan tinggi menjadi bingung antara harus menjelaskan Pancasila sebagai dasar negara atau bagian dari pilar negara. Sehingga, proses pembelajaran dan pendidikan Pancasila berjalan tidak efektif dan kondusif atas penggunaan bahasa Empat Pilar yang dilakukan oleh MPR RI karena telah mengacaukan pengetahuan generasi muda dan para pendidik.

\section{Simpulan}

Pendidikan Pancasila merupakan proses dalam memberikan pemahaman tentang nilainilai kebangsaan kepada generasi muda dan masyarakat secara umum. Pendidikan Pancasila menjadi tujuan dan cara pemerintah untuk mengenalkan dan menanamkan nilai- 
nilai kebangsaan secara berkelanjutan. Sosialisasi Empat Pilar MPR RI telah membawa perubahan paradigmatis dalam proses belajar mengajar pada pendidikan Pancasila di perguruan tinggi. Dampak sosialisasi Empat Pilar MPR RI dengan mengategorikan Pancasila, UUD 1945, NKRI, dan Bhinneka Tunggal Ika sebagai pilar telah merugikan proses pengajaran dan pendidikan Pancasila di perguruan tinggi. Dengan demikian, penelitian ini menyimpulkan bahwa (1) sosialisasi Empat Pilar MPR RI berdampak pada ketidakpastian pemahaman peserta didik dan dosen dalam mengajarkan Pancasila sebagai dasar atau pilar kehidupan bernegara dan berbangsa, (2) Empat Pilar MPR RI menimbulkan perdebatan di kalangan mahasiswa dan dosen terkait dengan dasar historis, ontologis, epistemologis, dan aksiologisnya, dan (3) penggunaan istilah Empat Pilar dalam sosialisasi Empat Pilar MPR RI sudah selayaknya dihentikan dan dihapuskan karena mengacaukan pemahaman dan pengetahuan para peserta didik dalam memahami Pancasila, UUD 1945, NKRI, dan Bhinneka Tunggal Ika dengan baik dan benar.

\section{Ucapan Terima Kasih}

Artikel ini merupakan bagian dari rangkaian riset disertasi yang telah dilakukan peneliti. Peneliti mengucapkan terima kasih yang sebesar-besarnya kepada Prof. Dr. Armaidy Armawi sebagai promotor Disertasi dan Prof. Dr. Kaelan sebagai ko-promotor yang selalu memberikan masukan dan saran untuk perbaikan disertasi dan berbagai kesempatan penulisan lainnya. Serta kepada Jurnal Civics Media Kajian Kewarganegaraan Universitas Negeri Yogyakarta yang telah menerbitkan karya riset disertasi ini.

\section{Referensi}

Airlangga, Z. C. (2017). Ironi empat pilar: proyek ratusan miliar. Diambil 15 Juni 2018, dari https://nusantara.news/ironi-empat-pilarproyek-ratusan-miliar

As'ad, S. A. (2009). Negara Pancasila jalan kemaslahatan berbangsa. Jakarta: LP3ES.

Edelman, M. (1985). Political language and political reality. $P S, 18(1)$.

Kaelan. (2012). Problem epistemologis empat pilar berbangsa dan bernegara. Yogyakarta: Paradigma.

Kaelan. (2014). Pendidikan Pancasila edisi reformasi 2014. Yogyakarta: Paradigma.

Kementerian Riset Teknologi dan Pendidikan Tinggi. (2016). Buku ajar mata kuliah wajib umum Pancasila (1 ed.). Jakarta: Direktorat Jenderal Pembelajaran dan Kemahasiswaan Kementerian Riset Teknologi dan Pendidikan Tinggi. https://doi.org/10.1007/s12032-011-9855-6

Mudhofir, A. (2006). Pancasila sebagai pokok pangkal sudut pandang bagi ilmu menurut Notonagoro. Jurnal Filsafat, 39(1), 27-33. https://doi.org/10.22146/jf.23213

Mulyoto, G. P., \& Samsuri, S. (2017). Pengaruh model project citizen dengan pendekatan saintifik terhadap penguasaan kompetensi kewarganegaraan dalam pembelajaran Pendidikan Pancasila dan Kewarganegaraan. Jurnal Civics: Media Kajian Kewarganegaraan, 14(1), 105-118.

Murdiono, M., Miftahuddin, \& Kuncorowati, P. W. (2017). The education of the national character of Pancasila in secondary school based on pesantren. Cakrawala Pendidikan, XXXVI(3), 423-434.

Sudaryanto. (2017). Kekeluargaan sebagai kunci pemahaman Pancasila. Jurnal Filsafat, $17(2)$, 151-165. https://doi.org/10.22146/jf.23156

Sumardjoko, B., \& Musyiam, M. (2018). Model of civic education learning based on the local wisdom for revitalizing values of Pancasila. Cakrawala Pendidikan, 37(2), 201-211. https://doi.org/10.21831/cp.v37i2.18037

Supeni, S. (2015). Pengembangan model internalisasi pendidikan karakter pancasila pada guru pendidikan anak usia dini. Cakrawala Pendidikan, XXXIV(1), 118-127.

Sutarto, Jaedun, A., \& Nuryadin. (2017). Dampak pengiring pembelajaran pendekatan saintifik untuk pengembangan sikap spiritual dan sosial siswa. Jurnal Cakrawala Pendidikan, $36(1)$, 44-56. https://doi.org/10.21831/cp.v36i1.12792

Tim Dosen Pancasila Pusat MPK Universitas Brawijaya. (2017). Pancasila dalam diskursus sejarah, jalan tengah, dan filosofi bangsa. Yogyakarta: Ifada.

Tim Kerja Sosialisasi MPR-RI. (2012). Empat pilar kehidupan berbangsa dan bernegara.

Jurnal Civics: Media Kajian Kewarganegaraan |109 
Jakarta: Sekretariat Jenderal MPR-RI.

Winarno. (2012). Pendidikan Pancasila di perguruan tinggi panduan praktis pembelajaran. Surakarta: Yama Pustaka.

Wreksosuhardjo, S. (2004). Filsafat Pancasila secara ilmiah dan aplikatif. Yogyakarta: Andi. 